\title{
SME policy and the Regional Dimension of Innovation : Towards a New Paradigm for Innovation Policy?
}

\author{
Claire NAUWELAERS and René WINTJES \\ MERIT - University of Maastricht \\ P.O. Box 616 \\ 6200 MD Maastricht \\ The Netherlands
}

\begin{abstract}
Based on the empirical findings achieved in a comparative research, involving 40 innovation policy instruments in 11 European regions, this paper exposes the claim for a new innovation policy paradigm and proposes a shift in rationale and in broad orientations for innovation policy, addressing SMEs in their regional context. The main role for innovation policy, which aims to increase the capacity of a region and the capabilities of its SMEs to innovate, is to foster interactive learning within the firms and within the region. This calls for an interactive mode of policy intervention.

The paper also deals with the question of how to build a coherent portfolio of policy instruments, taking into account both regional situations and specific SMEs needs in terms of innovation. The key message delivered is that there is no "one-size-fits-all" policy portfolio. Regional differences in innovation capabilities call for a tailored mix of policy instruments. One salient element of the conclusion is the need for more "policy intelligence" in this complex field.
\end{abstract}




\section{Introduction}

Innovation is ranking higher on policy agendas today, at national, European and regional levels. This evolution is nurtured by the understanding that innovation is the key to economic development for developed, high-wages countries. It is becoming visible through a gradual shift in policy statements from support to $R \& D$ and technology diffusion, towards the promotion of innovation. This change in focus reflects the efforts paid to meet the view that innovation is an interactive, rather than linear, process. Under such an understanding, traditional S\&T policies do not offer the unique response to this need to support innovative practices : many other elements than science and technology play a role in innovation, and need to be tackled by innovation policy. Envisaged under such an enlarged framework, innovation policies are still in their infancy.

The SMEPOL project, carried out under the "Targeted Socio-Economic Research" programme of the European Union, is a collaborative project of 7 academic research groups ${ }^{1}$, that addresses the question of the efficiency conditions for innovation policy, based on a comparative analysis of innovation policy instruments. The research targets instruments specifically developed for SMEs, and implemented at regional level. As shown in Figure 1, the analysis covers six key questions : What is the relevance of the policy instruments according to lessons from theory ? Do these instruments tackle real innovation needs from companies ? Do the means correspond to aims of the policy instruments ? What is the efficiency of the instruments (cost-benefit ratio) ? What are the results achieved by these instruments? What are their impacts ? How are the instruments co-ordinated with the rest of the policy system ? Those questions have been dealt with in 11 regional environments ${ }^{2}$, and for 40 policy instruments of various sorts : direct subsidies to firms (for R\&D projects or personnel), technological centres, mobility schemes for researchers, innovation brokers, clusters policies.

\section{- $\quad$ FIGURE 1 ABOUT HERE -}

The thesis at the core of the study is that the variety of regional contexts and the diversity of firms' abilities, attitudes, driving forces and barriers towards innovation prevents the search of one permanent 'best practice' policy, valid for each and every situation. This is not to say, however, that nothing general can be concluded, in response to the question of how to improve the efficiency of policy instruments to support innovation in SMEs. The comparison between the results of the analyses of a variety of innovation policy tools, based on the same conceptual background, has delivered responses to this crucial question. They form a rich scope of opportunities for better practice regarding the policy process of addressing innovation of SMEs in their regional context. If one may call the shift from a linear model of innovation towards an interactive one, a shift in paradigm, then the main goal of SMEPOL is to put in evidence a similar shift towards a new innovation policy paradigm. The aim of this paper is to enlighten the main elements of such a new policy paradigm.

The points of departure of this policy-oriented study is that innovation is a good thing (both on regional as well as firm levels) and that there is a call for public intervention in order to get

\footnotetext{
${ }^{1}$ University of Economics and Business Administration, Austria; Centre for Small Business Studies, Denmark; Universitá degli Studi di Pavia, Italy; Maastricht Economic Research Institute on Innovation and Technology, The Netherlands; The STEP Group, Norway (project coordinator); Universidad Autonoma de Madrid, Spain; and Middlesex University, The United Kingdom.

${ }^{2}$ Upper Austria, Wallonia in Belgium, the Triangle region in southern Jutland (Denmark), Lombardy and Apulia in Italy, Limburg in the Netherlands, northern and south-eastern Norway, Valencia in Spain, parts of London (Lee Valley) and parts of its outer metropolitan area (Hertfordshire).
} 
more of it. As a background, based on the literature, the theoretical part of the study builds on these basic assumptions. This part includes two main arguments, touching respectively on the role of SMEs, and of the regional level of decision, for innovation. Those are briefly summarised below.

First, the study argues that SMEs are an important target group for innovation policy ${ }^{3 i}$. It provides three distinctive characteristics of SMEs, which form the basis for arguments and implications for innovation policy addressed to SMEs. These distinctive characteristics (compared to larger firms) are : a limited resource base, a distinctive organisational culture linked to the proximity between ownership and management, and a lower ability to shape their external environment. These characteristics are at the roots of the more informal, uncodified character of management and innovation practices in SMEs, which call for distinctive policy approaches. According to this view, the thrust of policy approaches should be twofold : to increase the availability of external resources for SMEs and to develop their internal, absorptive and learning capacities. This points to the crucial role of intermediaries able to codify SMEs' needs, working on the basis of personal trust relations, to the value of "peer" networks as learning channels, and to the key role of human capital in SMEs.

Second, the study claims the importance of the regional dimension of innovation. The discussion develops the thesis that proximity linkages can be instrumental in developing "learning firms" and "learning regions". Broadening and extending the concept of clusters towards the one of development coalition, points to a broader scope for innovation policy too, i.e. that of supporting the social and cultural aspects of innovation, enhancing social capital as a key element behind well-functioning regional innovation systems. Developing collective capacities and networking practices at local level follows logically as policy aim, but this should also be complemented with support to the development of linkages at national and international levels, in order to avoid being trapped into too strong local ties, possibly leading to lock-in situations.

This paper is organised as follows.

Based on the empirical findings achieved in this comparative research, sections 1 and 2 expose the claim for a new innovation policy paradigm and propose a shift in rationale (section 1) and in broad orientations (section 2) for innovation policy, addressing SMEs in their regional context. These sections use the notions of market failures and system deficits, which show up as barriers to innovation processes in regions and SMEs, and focus on what we may call government failures, shown by the evaluation of instruments.

The key argument of this paper is synthesised in section 3, where a stylised view on the content of a sound regional innovation policy for SMEs is presented.

Section 4 deals with the question of how to build a coherent portfolio of policy instruments, taking into account both regional situations and specific SMEs needs in terms of innovation. The key message delivered is that there is no "one-size-fits-all" policy portfolio.

The concluding section draws the lessons from the whole exercise of evaluating, in a comparative fashion, a variety of policy tools, within a common conceptual framework. One salient element of the conclusion is the need for more "policy intelligence" in this complex field.

\section{The rationale for policy intervention in innovation :}

\footnotetext{
${ }^{3}$ These arguments have been developed by the British team in SMEPOL (Smallbone, D., North, D., Vickers, I. 1999b).
} 


\section{Failures in communication, barriers to innovation and boundaries to learning in SMEs and their regions}

Whether we talk about markets, systems or governments in relation to innovation, it all concerns communication, a process of exchanging information and knowledge. In order to be useful and valuable to others in a firm, market, system or government administration, technological (and other) knowledge has to be diffused and policy lessons have to be learned.

The typical and traditional approach to communication in business and economics focuses on markets where price mediates supply and demand. The "neo-classical" government typically communicates power based on a hierarchical position vis à vis the economic agents they govern. Moreover, in accordance with traditional market-hierarchy dichotomies, the typical argument for government intervention is where markets fail in communication. Either the market or the government would provide the best solution and, in general, interactive communication is not considered to be of vital importance in the process of finding and reaching solutions. The linear perspective dominated even before it had been applied to innovation.

If everybody knows in advance what (products, resources, technologies, capabilities etc.) we are talking about and everybody would agree on its (present and future) economic value, the market is perfectly able in communicating supply and demand. In these situations there is no need for communicative interaction. Whether the 'demander' or the 'supplier' names the price the market will in a linear response come up with the proper answer. For the exchange of certain goods or services the price may be the only aspect that has to be communicated. However, when knowledge or innovation is concerned, the market or price mechanism may not function very well.

Following the logic for policy, a central question for a policymaker is : how do I recognise where and when markets fail, so where and when do I intervene? If it is perfectly clear to policy makers where markets fail, and it is widely agreed upon, what the governed region additionally 'needs' and 'has to offer' (and more specifically what firms 'need' from their region including its government and what firms have to offer their region and its policy goals), then there is no need for interaction, because everything is clear and there is no knowledge left to be codified. There is only information to be passed on, and since interaction is costly, e.g. in terms of time and energy, linear and top-down communication is likely to be more efficient.

However, dealing with the uncertainties attached to knowledge and innovation, economic and policy agents may want to communicate more than price or authority. The traditional concept of markets and (state) hierarchies with their anonymous, linear and formal communication, fails to incorporate this. A reason why both markets and hierarchies as co-ordination and communication mechanisms may not function very well regarding innovation is related to the uncertainties attached to predicting the future. The market may fail to predict the economic value of new technologies, new products, new resources, new firms or new entrepreneurial capabilities. Typically, the market will, for instance, not be able to value a start-up firm. Although policy makers have difficulties in predicting the future either, this kind of market failure is a widely accepted justification for public intervention through, e.g., a generic national policy tool like a tax-reduction scheme. The latter seems relevant to 'protect' these young, new entrepreneurial experiments, providing them a chance to prove themselves and to convince the market (customers but also financial and labour markets for instance) of their potential, and moreover to convince the government of their potential contribution to the region and its policy goals. The same arguments may hold for new sectors or technologies or a young regional cluster of firms, or even older non-innovative firms that want to, and are trying to become innovative. The most obvious role for policy makers with regard to 
innovation is perhaps to support 'new people' providing them the chance to learn by educating them before they convince the labour market of their economic value.

Other aspects where market obviously fail, is in communicating certain environmental and social costs and benefits. If economic agents do not take these kind of 'costs' into account, governments may want to intervene and extend the boundaries of the rationality of the agents they govern, e.g. by influencing their cost-benefit calculations with environmental taxes.

The justification for traditional technology or R\&D policy is based on the macro-level argument that, when the social effects are taken into account, there is under-investment in $\mathrm{R} \& \mathrm{D}$. The risk and uncertainty attached to $\mathrm{R} \& \mathrm{D}$ by private actors calls for public intervention because, at the macro-level, it is considered worthwhile to publicly take the risk for the sake of society, e.g., by financing public R\&D in universities or, again, by influencing private, micro-level cost-benefit calculations with tax-deduction facilities or subsidies.

The idea that there is a role for policy makers if markets fail, does not imply that policy makers are perfect, but that the above mentioned general or structural market failures may very well be effectively and efficiently addressed by generic policy instruments, designed and delivered at the national policy-level. And to diffuse this information on needs and support, linear communication seems appropriate. However, knowledge differs from information. For instance, distance does not seem to be a barrier to the transmission of information, but in the transmission of knowledge it does.

The importance of the tacit dimension, the informal, uncodified and disembodied aspects of the knowledge concerned, both at the regional level and for SMEs, underlines the localised nature of knowledge spillovers. The linear communication using the old market-hierarchy approaches fails to address this. Proximity matters to knowledge spillovers and interaction between regional agents (both private and public) matters in dealing with the uncertainties attached to innovation processes in regions and SMEs. The variety of situations regarding innovation, SMEs and regions call for communicative interaction. Local discussions, private and public-private ones, can shed more light on the uncertainty issues. Exchanging tacit visions, converging ideas and co-ordinating investments decisions (public, private and public/private ones) may provide the knowledge base for an innovation strategy concerning SMEs and their regions.

Especially concerning innovation processes in regions and SMEs, the concept of systems (or networks or clusters) seems more appropriate to model the reality than the traditional concepts of markets and hierarchies. A regional innovation systems approach stresses the importance of diffusion of knowledge and interactive learning within the region as a system. The non-anonymous relations, the complementarity of activities, and the historical setting is stressed, which specifies the regional context and the profile of its SMEs. It provides the regional system its identity. In order to find out and articulate what a particular region or firm needs or what is lacking concerning innovation, regional proximity and communicative interaction may be needed to address the tacit and latent aspects. Providing R\&D taxreduction or subsidies may also not be enough to change the rationality (nor the boundaries) of SMEs regarding innovation processes.

\section{Policy lessons from the evaluation of 40 innovation policy tools in 10 European regions}

Having discussed the rationale for policy intervention in innovation, this section deals with the content of such policies, proposing general "rules" for their design and implementation 
(section 2.1) and observing how these "rules" match with practice in the case study regions (section 2.2).

\subsection{Basic principles for innovation support policies}

Building on the conceptual and empirical findings of the SMEPOL project, the analysis puts the following proposal forth :

Since the main distinguishing features of the majority of SMEs, with regard to the innovation process, are that : they have a limited resource base, need external orientation to understand and (pro-actively) adapt to their environment, and engage in innovation on an informal mode, the main role for innovation policy, which aims to increase the capacity of a region and the capabilities of its SMEs to innovate, is to foster interactive learning within the firms and within the region. This calls for an interactive mode of policy intervention.

Of course, this statement stands as a quite bold generalisation of both SMEs characteristics and policy challenge. Some SMEs have a quite advanced knowledge base (e.g. New Techonology-Based Firms), others have developed excellent innovation management capabilities and explicit innovation strategies, and some firms in niches really shape their business environment rather than being dependent on it. Also, there are problems of another nature which impede SMEs to innovate, such as the need for risk financing ${ }^{4}$ or the necessity to access technological state-of-the art. The meaning of this proposal is to point to orientation of policies, needed to address the key needs of the majority of SMEs in most regions, and which are not properly taken into account in traditional policy approaches. This does not imply that linear approaches and tools are not relevant anymore, but rather, it puts the latter in perspective. It means that providing resources to innovate (finance, technology) is not sufficient if the firms do not possess the managerial and organisational abilities to deal with the innovative process (Cobbenhagen, 1999). The view of an "automatic" flow of technological resources through the firm, or from the R\&D sector into the firm, is denied here, while increased attention is given to the innovation process (within and around the firm) itself, in a broader sense.

Fostering interactive learning, as a policy goal, should not be read in a dogmatic egalitarian sense, limiting the view to the development of "Third-Italy" type of horizontal networking and relationships, as an ideal way to foster that process. Hierarchical relationships might be very relevant ways to achieve such an objective too, depending on the environment. As developed in section 1, the role of geographical proximity might be important to nurture these learning relationships, but it is not a necessary ingredient everywhere. The point here is that being open to outside sources of knowledge, and having the capacity to integrate these with internal knowledge in the firm on a continuous mode, is a key to the innovation process. Such an objective has implications both on the supply-side (outside resources should exist, be organised and accessible to firms) and on the demand side (the firm's absorption capacity and its willingness to entertain links with the outside should be enhanced). Developing strategic capabilities, at firm, organisation and policy levels, lies at the heart of this challenge.

The idea of an interactive mode of implementation of policy means not only that services should be both designed and delivered in co-operation with the beneficiaries, but also, that the policy implementers can be partners in the supported action or project, so that learning can happen both ways between policy implementers and firms - what we called "communicative interaction" in section 1 above. This way, the tacit nature of innovation in SMEs is better approached than in more hierarchical policy modes.

\footnotetext{
${ }^{4}$ Even there, in most cases, the problem is not so much the existence of risk capital funds but the accessibility of these for SMEs engaged in risky, and sometimes weakly formalised projects.
} 


\subsection{The application of the basic principles in the SMEPOL study areas}

If the statement above is the challenge for policy in theory, how does it compare with practice, as experienced in the regions covered by the SMEPOL study?

The horizontal overview and comparison between the analyses of forty policy tools in eleven European regions, show that such a challenge is hardly met by the policies at work in these regions. Both the content and the modes of delivery of policies are in most cases not interactive and fit better with a market-hierarchy than a system approach.

More precisely, the SMEPOL analyses deliver the following picture:

1. The general situation is that linear tools are dominating the policy scene, but that everywhere an evolution towards more interactive support is visible.

2. Policy instruments in general do not form a system : lack of co-ordination and of synergies between tools at work in one region is the rule.

3. Few policy instruments are designed and implemented in an user-oriented mode, taking both expressed and latent needs of users into account : the majority of tools are developed in a reactive, top-down fashion and at best consider expressed (but not latent) firms' needs. However, in cases where "voice" of users is taken into account, the tools become much more user-oriented.

4. Policy learning is still rare and underdeveloped. If it occurs at the level of organisations, it takes place on an occasional, not routinised way. Intense policy learning practices may however result in undesirable volatility in the policy system. At the other extreme, it seems unjustified to maintain a range of tools that are virtually not used by firms. The challenge lies in fine-tuning the policy tools without letting firms suffer from the instability of the system.

5. There is an emerging new tendency of developing "overall schemes", gathering into a single programme or instrument and organisation, a set of tools traditionaly proposed separately to companies. This approach is promising in that it fits well with the global perception of innovation within firms.

6. The majority of instruments aim at improving or facilitating existing innovation projects, rather than inducing new innovation practices : providing grants for $\mathrm{R} \& \mathrm{D}$, e.g. seems to induce a rather small incremental behavioural effect (in terms of strategy, management or culture regarding innovation, co-operation and interactive learning). Therefore, the additionality of such policy instruments is questionnable. The question of penetration rate of the tools in the business sector is not always addressed in policy settings, e.g. where a "picking-the-winner" approach is taken : a focus on the visibility of results may act as detriment to the value-added of the scheme.

7. Very often, tools designed at regional level work under a closed vision of the relevant sources of knowledge useful for firms, as the boundaries of the system are defined in administrative terms. If tools would be more user-oriented, there is no need for such a restricted view.

8. Overall, there is a decreasing attention in the available policy support, for the 5 following types of main needs for innovation support reported by SMEs:

$>$ Finance /risk sharing

$>$ Technology /technical know-how

$>$ Qualifications/personnel

$>$ Market access/information

$>$ Time constraints/Organisation/Strategic capabilities.

The lack of "market orientation" of the policy tools, or their lack of focus on the commercialisation aspects of innovation are particularly put in evidence by the SMEPOL study. 


\section{A synthetic view on policy directed at innovation in SMEs in a regional context}

The SMEPOL study has revealed a high degree of heterogeneity in policy instruments aiming at fostering innovation in SMEs. The instruments have various goals, such a, for instance, linking SMEs with R\&D producing institutions or reinforcing human resources within companies. The support also comes in various forms, like direct financial support, or services from technological centres or brokers, or under the name of cluster policy. Some policies clearly have a national origin while others may be classified as regional. Moreover, and perhaps of more fundamental importance, the policy instruments touch on different entry points of the individual innovation path of firms. Or even different phases of the (collective) innovation path of the regional system these firms may belong to. For instance, the abilities and attitudes vis-à-vis innovation of firms targeted by awareness raising instruments differ from the abilities and attitudes addressed by "linear" instruments. Some tools might help to create the necessary awareness and capabilities in firms, so they can afterwards be supported with more standardised schemes when they have moved further on their learning curve. A proper sequence of instruments becomes then more appropriate than a search for universally and permanently adequate tools.

The evidenced diversity, of cause, is not a surprise considering the variety among SMEs, their regional contexts and most of all the innovation processes. Notwithstanding this multilayered diversity, we can construct a simple, crude two-dimensional classification of the policy instruments, which presents a synthetic view along two key issues concerning a shift or change in policy paradigm (see Table 1). We have classified the SMEPOL instruments according to the two following key fundamental characteristics :

- $\quad$ Target level of support : firm-oriented or (regional) system-oriented.

With the term system we explicitly refer to regional systems. This does not imply that national or global systems or networks are irrelevant bases for economic co-ordination, but it expresses the claimed importance of the regional environment for innovation in SMEs. Some tools focus on innovation and learning within firms while others focus on crossing firm boundaries, aiming for externalities or synergies stemming from complementarity within the region as an innovation system. The logic behind (regional) system-oriented support is based on the idea that the innovation capacity and performance of a regional system may be larger than the 'sum' of the internal innovation capacity and performance of the individual 'members' of the system.

- Form and focus of support : focused on allocation of resources as inputs for innovation or focused on learning aiming for behavioural additionality.

At one extreme the policy approach is to raise the endowment, the stock of given resources (in firms and regions) as inputs for innovation. In a reactive mode of intervention the policy instruments aim at increasing innovation capacity by making the necessary resource inputs available. The principal idea is that the window of opportunities and problems towards innovation and support are clear and that given the lack (and need) of certain resource-inputs, policy makers increase the innovation output by allocating resources, that is, providing the innovation inputs or increase their availability (again internally within the firm or externally, within the region). At the other extreme are the instruments which focus on learning, trying to change behavioural aspects like the organisational culture, the innovation strategy, management, mentality or the level of awareness. They focus on creating or changing the windows of opportunities and problems concerning innovation and innovation policies. The according mode of intervention is a pro-active and interactive one. The principal idea is that the involved agents (private and public, individually or collectively) learn by doing, by using and by interacting. Doing innovation, using resources and interacting with others improves 
the awareness, the behavioural routines and the rationality towards innovation (and innovation policy). These tools focus on the throughput, along the innovation process and again also the innovation policy process.

\section{- TABLE 1 ABOUT HERE -}

Each of the four quadrants of Table 1 can be traced back to its own theoretical background or tradition ranging from atomistic to holistic approaches, and solutions from neo-classical and evolutionary traditions. The typology incorporates them all, and in fact it is suggested that in practice none of them is irrelevant in aiming for a change in innovative performance. 'Linear' tools directly aim for more innovation performance, while 'interactive' tools address innovation behaviour, but addressing behaviour is only meaningful if, in the end, it results in better performance.

Every policy in principle aims at changing behaviour. Policy makers can affect the innovative behaviour of firms directly via subsidies and individual projects or indirectly via the provision of 'hard' or 'soft' public infrastructure and institutions like universities or a technology centre. In a neo-classical reasoning, providing subsidies as an input to the innovation process is an intervention method to affect the innovative behaviour of firms directly by influencing the choices based on the cost/benefit calculations of the agents. An input-subsidy for R\&D or for hiring an expensive high-educated employee for instance affects the decisions regarding resource allocation immediately.

A more evolutionary approach to policy incorporates learning. In this respect subsidies for $\mathrm{R} \& \mathrm{D}$ can provide a learning experience. Within a 'learning-to-innovate' framework, policy support can get an innovation process started and support a change in the innovative behaviour in firms or regions. The support may also result in the static effect of more innovation output, but more importantly it aims for dynamic effects, effects which goes on after the support stops. The argument for policy then becomes temporal. Timing and the exante conditions become important. The reasoning behind policy rather becomes a pro-active than a re-active one. The difficulty with reactive policy is to know exactly what is needed by the firm or the region. Some expressed needs may be 'over-supported' while others may be latent, neglected, tacit and not supported. The articulation of the need then has to become part of the policy process, albeit in an interactive way. Merely providing the resource inputs that the policymakers think are relevant may not be enough to induce a real change in future behaviour.

An example of the difference between reactive and pro-active tools can be provided by two instruments studied in SMEPOL, similar at first sight, but serving different purposes because one is more reactive and the other more pro-active. Both the RIT scheme in Wallonia and the KIM scheme in Dutch Limburg, are subsidies to hire personnel in SMEs for the conduct of innovative projects, and have the objective to target firms that are not yet innovative. In the Walloon case, the firm itself has to write a formal technological development project and submit the proposal to the administration, who will decide on the subsidy according to the quality of the proposal and the results of an audit in the firm. The person employed needs to be a technician. In the Limburg case, an intermediary (Syntens, the innovation centre), helps the firm identify when such a scheme would be useful, helps find the candidate as needed, and does not require a formal project as a condition for the allocation of the subsidy. The type of personnel employed is not restricted to people possessing technological competences, but can also cover commercial or managerial weaknesses in the firm. It is clear that the RIT is mainly responding to the financial need of the company. Many SMEs do not use the RIT, because the formal requirement to codify a technological development project constitutes a barrier, and 
also because other financial sources are more easily accessible. In the case of KIM, the focus is more on the change of behaviour of the firm and there is an interaction between the firm and the support provider, within a more open view on the innovation project.

Table 1 can be used to examine under which paradigm issues the 40 SMEPOL policy instruments are developed and implemented.

The A type of instruments may be classified as more "traditional" while D type of instruments seem more "innovative", but this does not mean that instruments in one of the four quadrants are intrinsically better than instruments in any of the other quadrants. There are still sound arguments for each and every type of tools. The question turns more into one of the choice of the appropriate policy portfolio, anticipating the needs of the region (see section 4 below). Concerning the resource oriented tools $\mathrm{A}$ and $\mathrm{C}$, the national policy level may in many cases be more relevant than the regional policy level, especially if the support is needed at firm level and the lack of (internal or external) resources for innovation is not region-specific.

The relevance of $\mathrm{A}, \mathrm{B}, \mathrm{C}$ as well as $\mathrm{D}$ type of tools not only relates to different regional conditions, like the intensity of existing co-operation practices, for instance. It also relates to the various identified distinctive characteristics of SMEs, which have to be dealt with. The size-related characteristics affect the needs for support as well as the way the support can be delivered effectively. SMEs' limited resource base, for instance, finds a response in A or C type of tools. The A type focusing on raising endowment within firms, and $\mathrm{C}$ type of tools raising endowments of the innovation system the SME is part of, or is 'invited' to be part of. SMEs' distinctive organisational culture and management practices receive a better response in B type of tools, which try to influence certain attitudinal and behavioural aspects within the SMEs. Less ability for SMEs to shape their environment, compared to larger firms, might be addressed by $\mathrm{D}$ type of tools. These tools have to tackle the external uncertainties smaller firms are typically faced with, by enhancing the capacity of the firm to understand its environment and to become part of it (e.g., by forming clusters). That is, to become pro- and interactive members of a regional innovation system rather than staying passive, unaware and incapable to adapt or to influence others towards adoption. This calls for external awareness, and tools which teach SMEs how to identify, value, use and develop regional resources and interact with resource-owners.

The correspondence between the distinctive characteristics of SMEs regarding innovation and the various policy approaches shows first of all that every of the four types of policy instruments is relevant and secondly that the instruments have to be conceived starting from SMEs needs, expressed as well as latent ones.

The main outcome of the SMEPOL study, achieved through comparing the SME innovation patterns analysis with the results of the policy instruments analysis, is that the policy tools are too much concentrated in category A (e.g. in the form of firms' subsidies) in Figure 1, and that there are few instruments in category D (e.g. support to cluster forming). All types of instruments are relevant to different types of firms and different types of environments (and at different points in time), but the main gaps in the support systems in the SMEPOL cases, are to be found in category D. In order to conduct a change in perspective, it seems necessary, however, in most cases to first develop instruments of the $\mathrm{B}$ and $\mathrm{C}$ type, before the system and agents become apt to implement and absorb D-type instruments.

As stated before, in any specific regional situation, there will probably be a need for a mix of A,B,C and D-types of instruments. For example, A- and C-type instruments will still be particularly relevant for New Technology-Based Firms and spin-offs. B-type instruments could be used for less innovation-aware firms : building internal capabilities is a necessary step in most cases before being able to participate in a D-type instrument in interaction with other innovating agents. 
If a region does not have a lot of innovative SMEs, providing ever more resources to the same group of innovative firms seems less appropriate than extending the number of innovators by approaching non-innovating SMEs with B-type of tools. Enhancing their learning process and preparing them for more interactive behaviour can sub-sequentially be supported by $\mathrm{C}$ or $\mathrm{D}$ type of tools. If there is no lack of innovators but they seem to innovate in relative isolation, C-type of tools might create more openness and stimulate the use of external resources in the region.

There are also arguments to develop linkages between tools of the various categories. In general, however, the proactive provision of internal and external learning experience with B and D type of instruments respectively, will create new clients, and new resource needs which may subsequently be effectively addressed with the reactive provision of internal or external resources. The other logical sequential link refers to the fact that a certain level of internal resources and learning experiences are needed before system oriented tools can be effective. This calls for the need of excellent co-ordination, and the development of synergies between all tools at work in the environment.

This discussion also links with the question of the relevance of different levels of authorities for the various policy activities like design, adaptation, learning, implementation and evaluation. Pro-active tools imply more freedom of action and closeness to beneficiaries, more likely to be found at regional level, while reactive, standard tools are more adapted to higher levels of authorities.

\section{The challenge of customising a policy portfolio to regional specificity's}

Regional differences in innovation capabilities call for a tailored mix of policy instruments.

This section, therefore, reflects on the question of the appropriate policy portfolio to be developed in a regional context. For this, characteristics of the region as a whole and SMEspecific challenges for innovation are taken as the point of departure. To achieve the objective of identification of policy portfolios, Table 2 below proposes a picture of the situation, which combines the results of the analyses gathered in the SMEPOL study, i.e., the analysis of the main potential deficits of regional innovation systems, and the analysis of the main firms barriers with regard to innovation. The combination of regional and firm's deficits should form the basis for the design of policy intervention.

\section{- TABLE 2 ABOUT HERE -}

The aim of Table 2 is to enlighten possible policy responses to certain innovation barriers, deficits or challenges at regional and firm level. Each cell of this table contains two elements : the objectives of policy tools and examples of appropriate instruments.

Such a table shows clearly that there is no "one-size-fits-all" policy system : it depends on the problems and opportunities to be addressed in the existing context. It also shows the need for policy to provide longer term and holistic support to innovation in all its aspects. But it is nevertheless possible to develop recommendations per category of firms problems (horizontal lines in the table), per regional context (vertical lines in the table), and per type of policy tool (within each cell, every tool can be benchmarked against the broad guidelines for policy and against similar tools of the same type). 
Facing such a table of possible instruments, it becomes clear that the main role of the policy maker becomes the setting-up of priorities according to the perceived problems in its region, in line with the main orientation set to the economic development policy of the region.

The main condition however for the usefulness of the proposed approach, as a guide to redesign innovation policies targeting SMEs, is that on the policy side too, learning processes are at stake, and adequate strategic capabilities are present. In trying to create learning firms within learning regions there is a need for learning governments.

This implies four things in particular:

1. that the regional situation, that is, the particular needs and opportunities (for innovation support) of SMEs and the regional innovation system as a whole are well mapped, communicated and understood by policy designers;

2. that the objectives set to policy instruments are clearly expressed ex-ante in a global coherent framework and that the expected results are measurable;

3. that the results and impacts of the instruments are monitored properly and then evaluated by an independent, third party;

4. that lessons from the evaluation are acknowledged and diffused and that they are confronted with the policy aims, in order to adjust the policy approach and its instruments accordingly.

In most of the regions studied in SMEPOL, deficiencies have been noted in all the aspects listed above : a detailed knowledge of the specificity's of the regional innovation system is often absent, not properly diffused in a language understandable by policy makers, or not updated with sufficient regularity; effects of policies are often measured in a "funds consumption" approach only; evaluation is not built in the design of the programmes; no real independent evaluation of results and impacts are undertaken in most cases; pilot, bottom-up experiments are not really assessed, and there is thus a failure to capture lessons from these experiments; and policy learning is in general underdeveloped.

\section{Conclusion}

Drawing on the SMEPOL findings we have questioned in this paper how policy directed at innovation in SMEs can be improved. After discussing several rationales for policy we came up with a main question, that is, did we witness an actual shift in policy paradigm or did we find arguments which call for a new policy paradigm? Our conclusion is that we have witnessed some shifts in practice, and that we have found sound arguments which support our claim that a shift in rationale is needed to improve the policy directed at innovation in SMEs.

More precisely, we used Table 1 in section 3 to discuss the way to combine tools that are reactive or pro-active and target internal processes in SMEs, towards tools that are proactive and target the externalisation of SMEs or the functioning of the regional innovation system.

We also proposed a reflection on policy mixes in section 4, using Table 2, showing clearly that similar SME problems need to be tackled differently according to the regional context, but also that there is scope for importing elements of good practices from one context into another.

With this discussion, we can conclude that such an analysis, with the three key features of :

- Matching the context and SME needs' pictures with the policy tools in each region;

- Confronting the policy tools with the lessons of theory; 
- Comparing results achieved with a range of policy instruments in different environments,

is suitable for improving SME innovation support policies in the EU regions.

The best way to evolve in such a direction however, would be to undertake such a strategic benchmarking exercise with the active participation of policy makers and policy implementers themselves. Theoretically sensible ideas could then be confronted with reality. 


\section{References}

Asheim, B, Isaksen, A, SMEs and the Regional Dimension of Innovation. The Norwegian Report. SMEPOL report no. 5, Oslo, 1999.

Cobbenhagen, J., Managing Innovation at Company Level, Universitaire Pers Maastricht, 1999.

Christensen, P.R., Cornett, A., Philipsen, K, Innovations \& Innovation Support for SMEs The Triangle Region of Denmark. SMEPOL report no. 2, Kolding, 1999.

Christensen, P.R., Cornett, A., Philipsen, K., Coherence of Innovation Policy Instruments. SMEPOL final report, Kolding, 1999.

Garofoli, G. (ed.), SMEs, Innovation Trajectories and Policies: The Case of Lombardy and Apulia. SMEPOL report no. 3, Pavia, 1999.

Garofoli, G. and Musyck B., Overview of regional innovation policy instruments. SMEPOL final report, Pavia, 1999.

Gil, J.A., Sáez Cala, A., Vázquez Barquero, A., Viñas Apaolaza, A., Results and Impacts of Policy Instruments, SMEPOL final report, Madrid, 1999.

Isaksen, A., Asheim, B., Remøe, S.O. (eds.), SME Policy and the Regional Dimension of Innovation. The Norwegian Report. SMEPOL report no. 5, Oslo, 1999.

Isaksen, A., National and regional contexts for innovation. SMEPOL final report, Oslo, 1999.

Kaufmann, A. and Tödtling, F., Innovation Support for SMEs in Upper Austria. SMEPOL report no. 1, Vienna, 1999.

Kaufmann, A. and Tödtling, F., Innovation Patterns of SMEs. SMEPOL final report, Vienna, 1999.

Nauwelaers, C., Schall, N., Wintjes, R., SME Policy and the Regional Dimension of Innovation: The Cases of Wallonia and Limburg. SMEPOL report no. 4, Maastricht, 1999.

Nauwelaers, C., Wintjes, R., Towards a new Paradigm for Innovation Policy ?, SMEPOL final report, Maastricht, 1999.

Smallbone, D., North, D., Vickers, I., McCarthy I., SME Policy and the Regional Dimension of Innovation: UK National Report. SMEPOL report no. 7, Middlesex, 1999.

Smallbone, D., North, D., Vickers, I., SME Policy and the Regional Dimension of Innovation: Background : the role and characteristics of SMEs. SMEPOL final report, Middlesex, 1999.

Vázquez Barquero, A., Gil, J.A., Sáez Cala, A., Viñas Apaolaza, A., Atienza Úbeda, M., SME Policy and the Regional Dimension of Innovation: The Spanish Report. SMEPOL report no. 6, Madrid, 1999. 
Figure 1 : Framework of analysis for the SMEPOL project

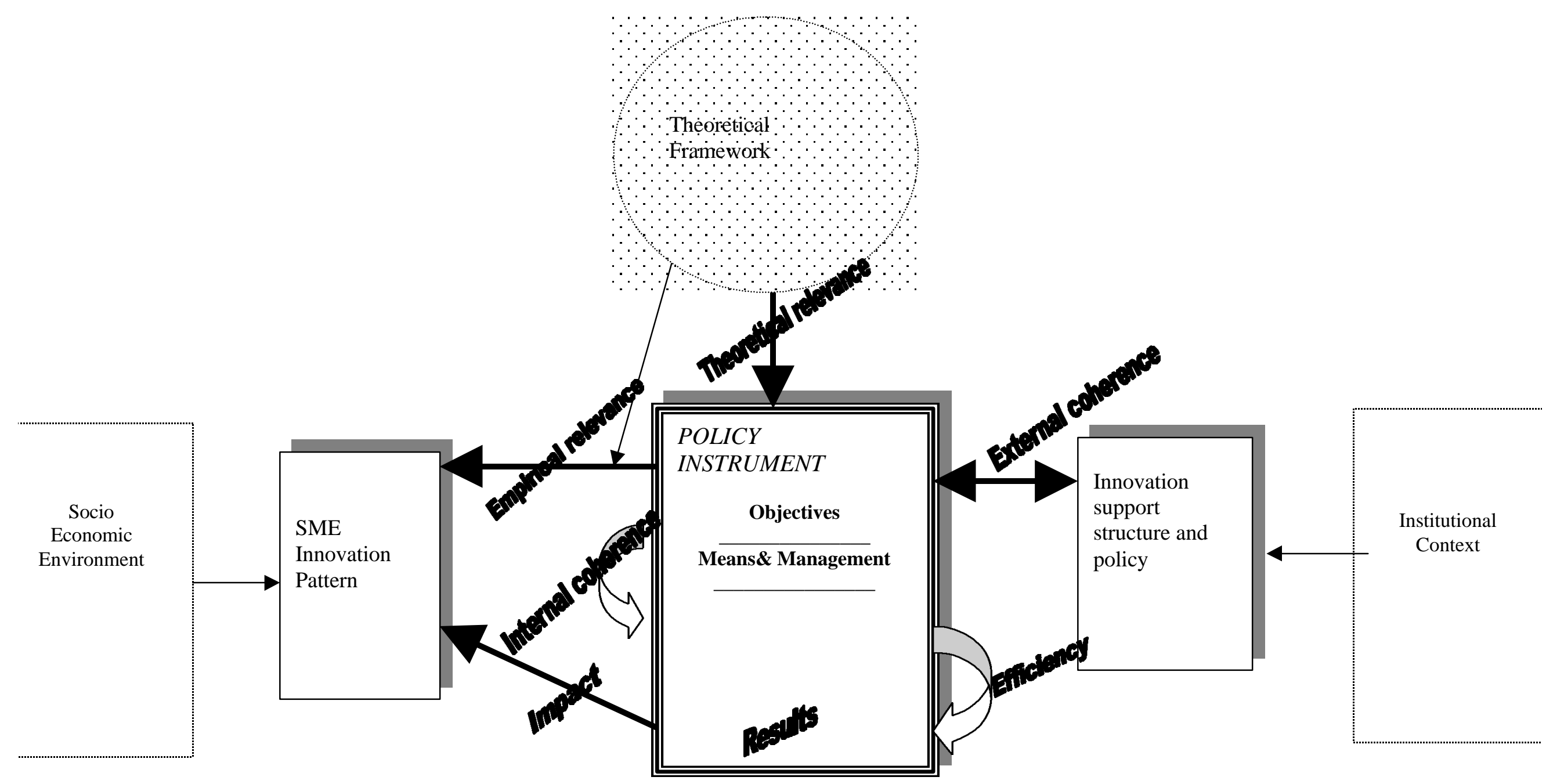



Table 1 : Classification of policy instruments studied in SMEPOL along two policy paradigm dimensions

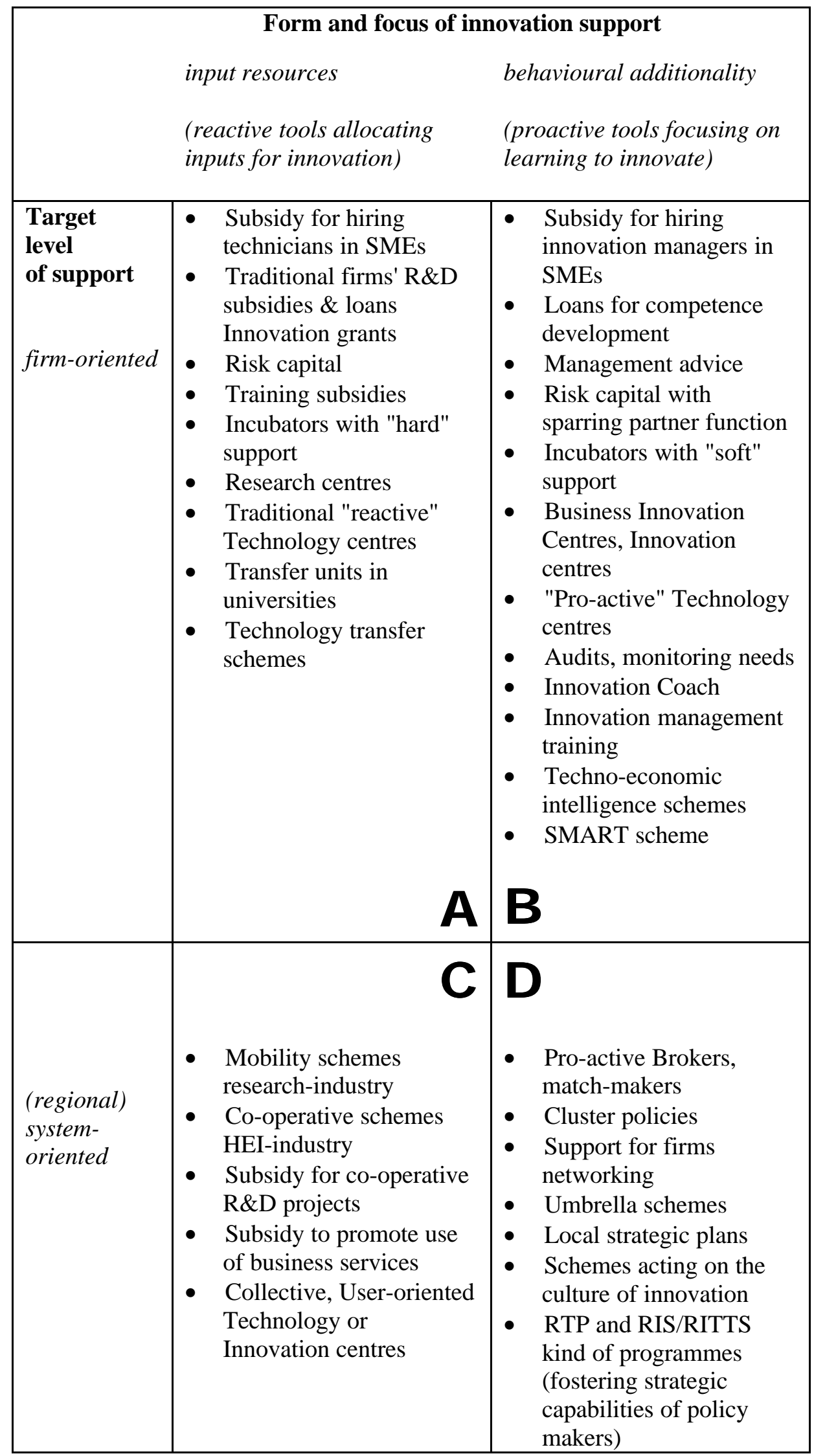


Table 2 : Policy responses to regions' and SMEs problems with innovation: an illustration of possible policy objectives and tools

\begin{tabular}{|c|c|c|c|}
\hline \multirow[t]{2}{*}{$\begin{array}{l}\text { SMES'N⿴囗十Sfor } \\
\text { INO/AIION }\end{array}$} & \multicolumn{3}{|c|}{$\begin{array}{l}\text { REOQALINDATIONSYSIEM } \\
\text { PRQARM }\end{array}$} \\
\hline & $\begin{array}{c}\begin{array}{c}\text { Organisational } \\
\text { thinness }\end{array} \\
\end{array}$ & \begin{tabular}{|l} 
Fragmentation \\
\end{tabular} & Lock-in \\
\hline $\begin{array}{l}\text { Financial } \\
\text { Getting capital } \\
\text { when markets } \\
\text { prefer secure } \\
\text { investments } \\
\text { with short term } \\
\text { return }\end{array}$ & $\begin{array}{l}\text { Attract and retain } \\
\text { innovating firms } \\
\text { Foster firms to go } \\
\text { global, link them to } \\
\text { international partners } \\
\text { and external financial } \\
\text { resources }\end{array}$ & $\begin{array}{l}\text { Coach firms in linking to } \\
\text { finance sources } \\
\text { Foster specialisation by } \\
\text { combining technological } \\
\text { support and finance } \\
\text { Support the formation of } \\
\text { sector-specific Venture } \\
\text { capital funds }\end{array}$ & $\begin{array}{l}\text { Ensure long term finance } \\
\text { for "overall" innovation } \\
\text { project : risk capital } \\
\text { Support new firm creation } \\
\text { :seed capital } \\
\text { Address succession } \\
\text { problems } \\
\text { Restructure mature } \\
\text { industries by attracting } \\
\text { FDI and promoting } \\
\text { international partnerships }\end{array}$ \\
\hline $\begin{array}{l}\text { Technological } \\
\text { Screening for } \\
\text { technological } \\
\text { options, } \\
\text { Adapting state- } \\
\text { of-the-art to } \\
\text { own situation }\end{array}$ & $\begin{array}{l}\text { Link firms with } \\
\text { technological resources } \\
\text { outside } \\
\text { the region } \\
\text { Promote collective } \\
\text { sourcing and } \\
\text { investments in collective } \\
\text { resources: } \\
\text { Technology centres } \\
\\
\text { Use private R\&D } \\
\text { centres as technology } \\
\text { resources for other } \\
\text { firms: Research } \\
\text { Vouchers }\end{array}$ & $\begin{array}{l}\text { Provide bridge between } \\
\text { firms and technological } \\
\text { resources } \\
\text { Brokers } \\
\text { Provide "accessible" } \\
\text { technology : co-operative } \\
\text { schemes HEI-SMEs } \\
\text { Finance firms to access } \\
\text { technology centres }\end{array}$ & $\begin{array}{l}\text { Push firms to seek for new } \\
\text { technology options: } \\
\text { Foster access to } \\
\text { resources outside the } \\
\text { region: } \\
\text { International partnerships } \\
\text { Restructure the } \\
\text { technology support } \\
\text { infrastructure towards } \\
\text { new technologies and } \\
\text { sectors }\end{array}$ \\
\hline $\begin{array}{l}\text { Human } \\
\text { resources } \\
\text { Using qualified } \\
\text { resources in } \\
\text { firms; } \\
\text { Investing in } \\
\text { training }\end{array}$ & $\begin{array}{l}\text { Attract/retain highly } \\
\text { skilled workers } \\
\text { Support collective } \\
\text { training programmes }\end{array}$ & $\begin{array}{l}\text { Foster exchange of } \\
\text { codified and tacit } \\
\text { knowledge } \\
\text { Teaching Company } \\
\text { Scheme } \\
\text { Foster intra-firm nodes } \\
\text { for co-operation : hiring } \\
\text { of researchers in SMEs }\end{array}$ & $\begin{array}{l}\text { Develop creative } \\
\text { capacities of workers: } \\
\text { Training schemes } \\
\text { Free personnel for } \\
\text { innovation } \\
\text { Subsidy to hire } \\
\text { technicians or innovation } \\
\text { managers }\end{array}$ \\
\hline
\end{tabular}




\begin{tabular}{|c|c|c|c|}
\hline $\begin{array}{l}\text { Openness and } \\
\text { learning } \\
\text { attitude } \\
\text { Learning from } \\
\text { others; } \\
\text { Developing } \\
\text { antennas to the } \\
\text { outside }\end{array}$ & $\begin{array}{l}\text { Promotion of } \\
\text { networking between } \\
\text { firms, and clusters at } \\
\text { every geographical } \\
\text { scale } \\
\text { Network of SMART } \\
\text { winners }\end{array}$ & $\begin{array}{l}\text { Foster a more } \\
\text { collaborative spirit and } \\
\text { more strategic orientation } \\
\text { in the regions } \\
\text { Regional Development } \\
\text { Agencies } \\
\text { Combine funding with } \\
\text { interaction stimulation } \\
\text { Umbrella schemes }\end{array}$ & $\begin{array}{l}\text { Help SMEs evolve } \\
\text { towards more creativity } \\
\text { and autonomy in } \\
\text { production } \\
\text { Supply-chain learning } \\
\text { Demonstration projects }\end{array}$ \\
\hline $\begin{array}{l}\text { Strategy \& } \\
\text { Organisation } \\
\text { Formalising } \\
\text { innovation } \\
\text { strategy } \\
\text { Integrating } \\
\text { commercial } \\
\text { orientation in } \\
\text { technological } \\
\text { projects }\end{array}$ & $\begin{array}{l}\text { Support firms in linking } \\
\text { to international input } \\
\text { and output markets } \\
\text { Develop systemic } \\
\text { character of innovation } \\
\text { support : } \\
\text { network brokers }\end{array}$ & $\begin{array}{l}\text { Help firms identify, } \\
\text { articulate and "de- } \\
\text { bundling" their needs : } \\
\text { Innovation coach, "SMEs } \\
\text { engineers" } \\
\text { Invite firms collectively to } \\
\text { help in formulating a } \\
\text { regional innovation } \\
\text { strategy: } \\
\text { RIS/RITTS }\end{array}$ & $\begin{array}{l}\text { Open windows of } \\
\text { opportunities for SMEs : } \\
\text { techno-economic } \\
\text { intelligence promotion } \\
\text { schemes } \\
\text { Innovation management } \\
\text { training }\end{array}$ \\
\hline
\end{tabular}

